\title{
Apostolic Legates in Poland in the Middle Ages and Their Role in Adopting Particular Ecclesiastical Legislation by the Polish Church - Educational Aspects
}

\begin{abstract}
The official reception of the conciliar legislation in medieval Poland was greatly influenced by the papal legates, ambassadors endowed with papal authority, who brought conciliar canons to the country ruled at the time by the Piasts and made them public at councils convened with the participation of papal legates, closely monitored the observance of Canon Law and its scope expansion, concurred statutes of Polish provincial and diocesan councils, approved or rejected nominations of bishops, etc. They also acted as intermediaries in personal interventions of popes in their involvement in the functioning of the Church in Poland. Their duties also included inspections in dioceses. Visits of papal legates in Poland were relatively frequent and their main goal was to enforce and implement ecclesiastical reforms in the country. In some instances, a strict relationship between a stay of a papal representative in Poland and the process of the creation and spread of schools is clearly observable. The article examines source accounts concerning the visits of papal legates in Poland, as well as analyses the available statues of legate councils in terms of the provisions included in them regarding education of representatives of the clergy and laymen alike.
\end{abstract}

Keywords: apostolic legates, Poland, church legislation, Middle Ages, history of education

One of the most important factors that contributed to the reform of the Church, while strengthening its culture-forming role in medieval Europe, was the institution of Apostolic legate. Deep reforms were initiated by Pope Leo IX (1048-1054), who at the synods presided over by him instructed that bishops and priests undertake the catechisation of the faithful ${ }^{1}$. The reform was carried out by the successive Popes: Nicholas II, Alexander II, and especially Gregory VII after whom the reform is referred to as Gregorian. The reform was designed to enforce the statutes and legal norms applicable within the Church, to make the Church independent on secular factors, and to return to the principles of evan-

\footnotetext{
${ }^{1}$ KUMOR, B., Historia Kościoła, vol. 2: Wczesne średniowiecze chrześcijańskie, Lublin 1973, p. 100.
} 
gelical life ${ }^{2}$. The reformatory work required direct intervention in the life of particular churches, which was performed by way of visits of Holy See representatives. Apostolic legates were granted temporary rights as representatives of the popes and were sent to given countries or regions of the continent to carry out relevant reforms. These reforms were implemented via legatine synods with participation of the episcopate of a given country. During these assemblies, the legates issued canons applicable in a given country or group of countries ${ }^{3}$. Legatine synods were mainly intended to implement universally-binding legislation in individual provinces of the Church. On such synods, various bulls, ordinances, decrees of popes and general councils, canons of the universal church law and finally ordinances of the legates themselves were announced ${ }^{4}$. It should be noted that legates made decisions referring to the Church in Poland also during legatine synods held outside Poland. Popes devolved some of their rights to legates, but decisions of the latter were not always final, because only the pope had full authority under canon law. Apostolic legates often began their missions immediately once synods in Rome or general councils had been concluded, to acquaint local churches with their arrangements. Numerous issues raised by the legates included also those related to education in a broad sense. The legates also approved, on behalf of the papacy, the wording of canons of Polish provincial and diocesan synods, confirming their conformity with the universally binding law ${ }^{5}$.

The aim of this paper is to examine the forms and extent of influence of representatives of the Holy See on the educational changes on Polish lands in the Middle Ages. To properly assess the importance of the activities of papal legates, it must be clearly stressed that the purpose of their visits was not educational reforms. These issues were of secondary importance to representatives of the papacy, but this does not mean that the legates did not take direct action aimed at improving the state of education, level of education of the clergy, quality of religious life, including religious education of the faithful.

Direct contacts between Poland ruled by the Piast dynasty with the Holy See date back to ca. 985-992 when Duke Mieszko I subjected his country to the protection of Saint Peter in the document which to this day raised controversy and discussion, called Dagome Iudex ${ }^{6}$. Initially, they were not very intense, but gained intensity in the second half of the

${ }^{2}$ KŁOCZOWSKI, J., Dzieje chrześcijaństwa polskiego, Warsaw 2000, p. 21 et seq.; See also: PARAVICINI BAGLIANI, A., Kościót rzymski w latach 1054-1124: reforma i umocnienie papiestwa, [in:] Historia chrześcijaństwa. Religia, kultura, polityka, ed. J.M. MAYER et al., vol. 5: Ekspansja Kościoła rzymskiego 10541274, ed. A. VAUCHEZ, Warsaw 2001, p. 52-85.

${ }^{3}$ More on the topic: PARISSE, M., KŁOCZOWSKI, J., Władcy chrześcijańscy a Kościót. Spór o inwestyturę i jego skutki, [in:] Historia chrześcijaństwa, vol. 5, p. 94 et seq.

${ }^{4}$ SUBERA, I., Synody prowincjonalne arcybiskupów gnieźnieńskich. Wybór tekstów ze zbioru Jana Wężyka z r. 1761, Warszawa 1981, p. 28.

5 Ibidem, p. 31.

${ }^{6}$ Kodeks Dyplomatyczny Śląska, [hereinafter referred to as KDŚ], vol. 1, Wrocław 1956, no. 2. The literature on this document is vast. Cf. a review of position on the topic: BUCZEK, K., "Zagadnienie wiarygodności regestu Dagome iudex", Studia Źródłoznawcze, 1965, 10, p. 132 et seq.; LABUDA, G., Jakimi drogami przyszło do Polski chrześcijaństwo?, [in:] Idem, Szkice historyczne X-XI wieku. Z dziejów organizacji Kościoła w Polsce we wczesnym średniowieczu, Poznań 2004, p. 115 et seq. 
eleventh century, due to the need to rebuild the Polish church organization which was severely damaged during the crisis of the Piast state.

An important question is when the first legates arrived in Poland. The literature states that "it cannot be ruled out that the first bishop Jordan, who came to Poland and baptised Mieszko I, was consecrated in Rome and sent to Poland as a papal legate"7. However, this statement cannot be confirmed by any historical source. It can not be also ruled out that Archbishop Bruno of Querfurt acted as a legate in Poland ${ }^{8}$. Probably the first visit of papal representatives in Poland evidenced in historical sources was the mission carried out in 1075 on behalf of Pope Gregory VII, and related to the renewal of the Archdiocese of Gniezno and the Bolesław II the Bold quest for the royal crown. When sending legates to Poland, the Pope obliged them to renew the church administration in a country which still had traces of turbulent events from the crisis of statehood in the $1030 \mathrm{~s}^{9}$. The care for proper religious teaching of the faithful of the Church in Poland stems from the Pope Gregory VIIl's letter to Duke Bolesław the Generous dated $1075^{10}$. The Pope sent to Poland legates who consecrated the new metropolitan Bogumił and bishops, and cathedral schools in Gniezno ${ }^{11}$ and Krakow ${ }^{12}$ were founded. At that time, a bishopric was also established in Płock $^{13}$, and the diocese of Poznań ${ }^{14}$ resumed its activity. Cathedral chapters were established at cathedrals. Gregory VII strongly emphasized, through his legates, the necessity of religious teaching of the faithful. Of course, the teaching was to be delivered in the language of the people.

The next legations were sent in the times of Bolesław III Wrymouth. In 1105, a bishop synod was convened by Bishop of Beauvais Gallon, a representative of Pope

7 The author of this concept is KUMOR, B., Historia Kościoła w Polsce, vol. 1: do roku 1764, part 1: do roku 1506, ed. B. KUMOR, Z. OBERTYŃSKI, Poznań-Warsaw 1974, p. 37.

8 Ibidem, p. 41.

${ }^{9}$ Kodeks Dyplomatyczny Wielkopolski, [hereinafter referred to as $K D W$ ], vol. 1, Poznań 1877, no. 4: "Deinde vero, quod inter tantam hominum multitudinem adeo pauci sunt episcopi et ample singulorum parochie, ut in subiectis plebibus curam episcopalis officii nullatenus exequi aut rite administrare valeant". See: GRUDZIŃSKI, T., Polityka papieża Grzegorza VII wobec państw Europy Środkowej i Wschodniej (1073-1080), Toruń 1959.

${ }^{10}$ Das Register Gregors VII, ed. E. CASPAR, [in:] Monumenta Germaniae Historica. Epistola selectae, Bd. 2, Berlin 1920-1923, reg. II, p. 73. For a commentary, see: SKWIERCZYŃSKI, K., Recepcja idei gregoriańskich w Polsce do początku XIII wieku, Wrocław 2005, p. 46 et seq.

11 The consecration of the cathedral itself, rebuilt after having been destroyed, took place in 1064, while the new archbishop appeared just before 1076, perhaps due to the efforts of legates of Pope Gregory VII.

12 SKWIERCZYŃSKI, K., Recepcja idei gregoriańskich, p. 47-48.

13 DERWICH, M., Mogilno i Płock. Z dziejów budowy organizacji Kościoła polskiego, [in:] Civitas et Villa. Miasto i wieś w średniowiecznej Europie Środkowej, Wrocław-Praha 2002, p. 463 et seq.

14 BANASZAK, M., "Biskupstwo poznańskie (problemy badawcze średniowiecznych dziejów)", Nasza Przeszłość, 1988, 69, p. 5-9. Some scholars state that it is impossible to accurately specify the date of reinstatement of the Poznań bishopric. See: DOBOSZ, J., Monarchia i możni wobec Kościoła w Polsce do początku XIII wieku, Poznań 2002, p. 125-130. 
Paschal $\mathrm{II}^{15}$. During this legation, two bishops (of Krakow?, Poznan or Płock) were dismissed, perhaps mainly due to the fact that they belonged to the camp of supporters of his brother Zbigniew, who opposed Bolesław ${ }^{16}$. Bishop of Beauvais himself was praised by Gallus Anonymus for keeping strict compliance with the canon law ${ }^{17}$. In 1123, the papal legate Gilles de Paris (bishop of Tusculum), with the participation of Prince Bolesław Wrymouth, established two new bishoprics in the region of Kuyavia - in Kruszwica and in Włocławek ${ }^{18}$. They did not last long, because the seat of bishops of Kruszwica was moved in ca. 1157 to Włocławek, thus establishing one merged diocese for Kujawy. The third bishopric resulting from missions of the legates, was the bishopric of Lubusz. The significance of the legateship of Gilles of Tusculum is even greater because, in principle, the borders of the Polish dioceses drawn up in the years 1123-1124 were later strictly adhered to.

With time, stays of papal legates in Poland became more and more frequent, and these visits were intended mainly to implement ecclesiastical reforms ${ }^{19}$. In the first half of the twelfth century, the papal legates were Gallo and Gilles of Tusculum. Pope Eugene III sent Cardinal Humbald (1146) $)^{20}$ and Cardinal Guido (1148-1149) to Poland ${ }^{21}$. The latter intervened in the case of Władysław II the Exile and his wife (which is discussed in more detail below), he also dealt with some church matters. Unfortunately, there are no sources available in this case ${ }^{22}$. It is also worth noting that Cardinal Guido, as an apostolic legate in Bohemia in 1143, carried out a reformist synod, introducing celibacy among the clergy there, as Monk Sazawski put it: he "separated priests with their spouses"23. Polish visits of both legates of Pope Eugene III should therefore be associated with the adoption of

15 GĘBAROWICZ, M., "Walo biskup Beauvais z Paryża i jego legacja w Polsce”, Sprawozdania Towarzystwa Naukowego we Lwowie, 1923, 3, vol. 1.

${ }^{16}$ DOBOSZ, J., Monarchia i możni, p. 173 et seq.; KUMOR, B., Historia Kościoła, vol. 3: Złoty okres średniowiecza chrześcijańskiego, Lublin 2005, p. 54-55.

${ }^{17}$ GALL ANONIM, Kronika czyli dzieje książat $i$ władców polskich, ed. K. MALECZYŃSKI, [in:] Monumenta Poloniae Historica [hereinafter referred to as MPH]. Series nova, vol. 2, Kraków 1952, book 2, c. 27 .

${ }^{18}$ LABUDA, G., "Początki diecezjalnej organizacji kościelnej na Pomorzu i na Kujawach w XI i XII wieku”, Zapiski Historyczne, 1968, 33, vol. 3, p. 40.

${ }_{19}$ GROMNICKI, T., Synody prowincjonalne oraz czynności niektórych funkcjonariuszów apostolskich $w$ Polsce do r. 1357, Kraków 1885. See also: SKWIERCZYŃSKI, K., Recepcja idei gregoriańskich w Polsce do początku XIII wieku, Wrocław 2005.

${ }^{20} \mathrm{KDW}$, vol. 1 , no. 12 .

${ }^{21} K D W$, vol. 1 , no. 14 ; no. 16 ; $K D S$, vol. 1 , no. 21 ; no. 23 ; no. 24 ; no. $28-30$.

22 This could refer to discipline among the clergy and celibate. See $K D S$, vol. 1, no. 28, p. 74-75: “-sententiam autem, quam circa adverarios ducis Wladislai et sororis vestrae promulgavimus, domnus papa et Romana aecclesia firmaveruntr. - - ecclesia negotia, tanquam apostolacie sedes legatu, tractaret".

${ }^{23}$ As cited in: Kronikarze czescy. Kanonik Wyszehradzki, Mnich Sazawski, translated and compiled by M. WOJCIECHOWSKA, Warszawa 1978, p. 186. 
the ideals of the Gregorian reform in Poland. In the years 1167-1187, Legate Reinald ${ }^{24}$ arrived, in 1184 Bishop of Modena Gilles ${ }^{25}$, in 1189 Giovanni Malabranca $^{26}$. In 1197 the legateship was exercised by Peter of Capua. This latter convened synods in Lubcza and $\mathrm{Krakó}^{27}$. The legate also conducted visits to Polish dioceses, addressing the issue of celibacy of priests and church marriages ${ }^{28}$. His legation is regarded as the culmination of the first period of the Gregorian reform of the Church in Poland. The intensification of visits of the apostolic legates in the second half of the century was undoubtedly due to the implementation of decisions made by the Third Lateran Council of 1179. This council obliged bishops to maintain a teacher at each cathedral church, whose task was to teach clerics and students free of charge, in exchange for a relevant benefice ${ }^{29}$.

Even more important for the history of medieval education was the Fourth Lateran Council of $1215^{30}$. The programme of reform of ministry and ecclesiastical education in a broad sense consisted of the following canons: "On appointing preachers", "On schoolmasters for the poor", "On yearly confession to one's own priest, yearly communion" and "Candidates for the priesthood to be carefully trained and scrutinized ${ }^{31}$ ". They contained a series of orders regarding pastoral care of lay people, as well as discipline and education of the clergy. It was extremely important to consider the further development of ecclesias-

${ }^{24}$ He convoked a synod in Jeżów, Codex Diplomaticus Poloniae, vol. 1, Warsaw 1847, no. 87; Kodeks Dyplomatyczny Katedry Krakowskiej, no. 2, p. 4-5.

25 The legate brought relics of Saint Florian to Krakow. Jan Długosz notes about his stay in Poland Annales seu Cronicae incliti Regni Poloniae, lib. V-VI, Warsaw 1973, p. 135: "Egidius episcopis Mutinensis a duce Kazimiro et Gedeone Cracoviensi episcopo magnificis onustus muneribus Romam remissus".

${ }^{26}$ Joannis Dlugossii, Annales seu Cronicae, lib. VI, p. 146: "Poloniam ecclesiam Clemens papa tercius in membris et capite reformatus, et pro impensis ad defendendam Terram Sanctam, cuius recuperacionem magno avidore zelebat, subsidium a clero Polonie percepturus, Iohannem cardinalem cognomine Malabranka Poloniam transmittit - - qui sindum omnibus provinciae Gneznensis episcopis in civitate Cracowiensi indixit et aliquas constitutiones ad reformandum clerum promulgavit".

27 The visit is mentioned in Rocznik kapituly krakowskiej, [in:] MPH, vol. 2, p. 800: Petrus cardinalis venit in Poloniam sedis ap. Legatus qui instituit matrimonium contrahere in facie ecclesiae. See also: Joannis Dlugossii, Annales seu Cronicae, lib. 6, p. 166 et seq: "Petrus tituli Sancte Marie in Via Lata diaconus cardinalis, Capuanus vulgaliter nuncupatus, a summo pontifice Celestino tercio legatus de latere ad reformandam Ecclesiam Polonicam destinatus venit Poloniam"; further on, there is information about synods held in Lubcza and Kraków See: ZIELIŃSKI, J., “Legacja Piotra z Kapui do Czech i Polski w r. 1197”, Collactanea Theologica, 1957, 28, no. $3-4$, p. $576-597$.

${ }^{28}$ SKWIERCZYŃSKI, K., Recepcja idei gregoriańskich $w$ Polsce, p. 288 et seq.; KUMOR, B., Historia Kościoła, , vol. 3, p. 165.

${ }^{29}$ See more in: RATAJCZAK, K., "Ustawodawstwo szkolne soborów od XII do pierwszej połowy XIV w. i początki jego recepcji w średniowiecznej Polsce - zarys problemu”, Biuletyn Historii Wychowania, 2007, 23, p. 7-19; Idem, Ustawodawstwo szkolne wczesnośredniowiecznych soborów powszechnych i wybranych synodów. Zarys problemu, [in:] Ars Educandi. Źródła, vol. 1: Studia z dziejów wychowania i kształcenia od średniowiecza do XIX wieku, ed. J. GWIOŹDZIK and P.P. BARCZYK, Mysłowice 2009, p. 13-25.

${ }^{30}$ MALECZEK, W., Laterankonzil IV, [in:] Lexicon des Mittelalters, Bd. V, München-Zürich 1991, k. $1742-1744$.

31 Dokumenty soborów powszechnych, vol. 2 (869-1312), compiled by A. BARON, H. PIETRAS SJ, Kraków 2002, p. 244 et seq. 
tical education as a priority, especially as education was of great interest among burghers at that time, which in turn contributed to the significant development of municipal schools. The adoption of these canons was undoubtedly the reason for numerous legations of papal representatives to Poland in the 13th century. The series of legations which were intense in reformatory terms was opened by Cardinal Gregorio de Crescentio (1221). In subsequent years, the visits by William, Bishop of Modena (1230-1237), and Opizon, Abbot of Mezzano (1246 and 1253/1254) took place. They convoked legatine synods, under which the norms of ecclesiastical law and the principles of the Gregorian reform took roots in Poland. In 1248, Jacques of Leodium (Liège), who later became Pope Urban IV ${ }^{32}$ presided over a synod, while in 1253 the legates Gerard and Hugo ${ }^{33}$ came to Poland, while in 1267 Wrocław hosted papal legate Gwido, who also visited the dioceses ${ }^{34}$. A few years earlier, also papal legate Anzelm, the Bishop of Warmia, appeared in the capital of Silesia ${ }^{35}$. Since then, visits of apostolic legates have become frequent, and were associated not only with disciplinary issues, but also with various financial levies for the Roman Curia, or, for example, ongoing beatification and canonization processes. The legates demanded that each Polish bishop have a copy of the statutes and that their text be read out during diocesan synods $^{36}$. The legates emphasized the importance of changes in parish teaching, demanding a more in-depth explanation of the law and moral commandments aimed at eradicating usury, homicide, sacrilege and lust, or, briefly, better formation of the parishioners' morality by the clergy. Much consideration was devoted to family, sacramental life, obligation of the faithful to attend the Mass ${ }^{37}$, and the obligation of the clergy to preach and catechise $^{38}$.

In a few cases, we can see a close relationship between the papal representative's stay in Poland and the process of establishing schools. This was the case of Guido's legation in Wrocław in 1267, or, for example, Nicholas of Ostia, who stayed in Poznań in May 1302, which can be linked to the document of the Bishop of Poznań Andrew, dated July

${ }^{32} K D W$, vol. 1, no. 274; Kronika Wielkopolska, ed. B. KÜRBIS, [in:] MPH. Series Nova, vol. 7, Warsaw 1970, chapter 84. See: GÓRALSKI, W., “Statuty synodalne legata Jakuba z Leodium”, Prawo Kanoniczne, 1984,27 , no. $3-4$, p. 158 et seq.

${ }^{33}$ Rocznik wielkopolski, [in:] MPH, vol. 3, Lwów 1878, p. 27.

34 Schlesisches Urkundenbuch, Bd. IV, Köln-Wien 1988, no. 5, p. 4-9; KDW, vol. 1, no. 423; SILNICKI, T., Kardynat legat Gwido, jego synod wrocławski w r. 1267 i statuty tego synodu, Lwów 1930.

${ }^{35}$ ABRAHAM, W., Studia krytyczne do dziejów średniowiecznych synodów prowincjonalnych Kościoła polskiego, Kraków 1917, p. 18 et seq. His stay could have been related with the canonization process of Duchess Jadwiga.

${ }^{36}$ Legate Gwido ordered in 1267: "Volumus autem - - constitutiones nostras - - in synodis episcopalibus et in provinciali consilio faciant recitari et diligentius observari, et ea quae tangunt laicos faciant per parochiales ecclesias suorum dioecesanorum publicari". Antiquissimae constitutiones sinodales provinciae Gnesnensis. Maxima ex patre nunc primum e condicibus manu scriptis typis mandata, ed. R. HUBE, Petropoli 1856, c. 11; more recent edition: Schlesisches Urkundenbuch, Bd. IV, no. 5.

37 See more on the topic: SKIERSKA, I., Obowiązek mszalny w średniowiecznej Polsce, Warsaw 2003, p. $30-38$.

${ }^{38}$ KUMOR, B., Historia Kościoła, vol. 3, p. 170. 
and August of that year, regarding the school at the parish of St. Magdalene ${ }^{39}$. Also in the fourteenth century, apostolic legations to Poland were frequent and related to reforms in the Polish Church ${ }^{40}$.

By virtue of the legislation of the Wrocław synod presided over by Papal Legate Jacques, archdeacon of Liege (Leodium) in 1248, the teaching of basic texts of prayers in Polish was introduced to the teaching practice of all church schools ${ }^{41}$. Legate Jacques ordered also that, in order to strengthen the Christian faith, people be preached sermons explaining the content of the Mass readings ${ }^{42}$. The legate presented the Polish episcopate also with the Pope's opinion on the organisation of liturgy about the need of greater activity of the faithful during the Mass. This, in turn, resulted from better religious teaching provided to the faithful during ecclesiastical ceremonies.

In 1267, Legate Guido spoke about the curriculum of the newly established school in Wrocław at the church of St. Magdalene. It included learning to write, read, count and basics of Latin grammar. Equally important was the sphere of religious teaching, including basic prayers, the teaching of psalms and ecclesiastical singing ${ }^{43}$.

The Fouth Lateran Council pointed to the necessity to make the faithful more active during Holy Mass, so Legate Jacques of Leodium staying in Poland in 1248 ordered better educated priests to explain to the faithful the importance of the sacrament of communion ${ }^{44}$. During that synod, the need to bring the faithful closer to the parish was emphasized, which was related to the sacraments, and the obligation to announce banns of marriage and perform the very wedding ceremony "in front of the Church" i.e. in the presence of a priest. We can guess that appropriate teachings were given on this occasion, presenting the position of church authorities in the matter of marriage. The legate thus combat-

${ }^{39} \mathrm{KDW}$, vol. 2, no. 852 (Legate's document) and no. 855 (document of the Bishop of Poznań).

${ }^{40}$ For example: When staying in Poznań in 1309, Legate Gentilis enacted statutes for the Polish Church, $K D W$, vol. 2, no. 953 .

${ }^{41} \mathrm{KDW}$, vol. 1, no. 274: "De Oracione dominica et Symbolo exponendo. Denique vobis iniungimus ut in vestris Synodis presbyteris iniungatis, quatinus singulis diebus dominicis et festivis post Ewangelium dicant publice in vulgari suo Oracionem dominicam et Symbolum, vel ad minus Oracionem dominicam in latino et Symbolum in vulgari. Vidimus enim in vestris dyocesibus aliquos centenarios homines, qui nesciebant omnino dicere quid credebant". More recent edition of the statutes: Schlesisches Urkundenbuch, Bd. II, ed. W. IRGANG, Wien-Köln 1978, no. 346, p. 213.

42 This was to be done by "presbyteris eruditi", $K D W$, vol. 1, no. 274, p. 234.

${ }^{43}$ Schlesisches Urkundenbuch, Bd. IV, no. 7, p. 11: “-- pueri doceantur et discant alphabetum cum oratione dominica et salutationem beate Marie virginis cum symbolo, psalterio et septem psalmis, discant etiam ibidem cantum, ut in ecclesis ad honorem dei legere valeant et cantare, audiant etiam in eisdem scolis Donatum, Cathonem et Theodolum ac regulas pueriles".

${ }^{44} K D W$, vol. 1, no. 274: "Quocirca mandamus, ut quam cito presbyter fuerit requisitus ut ad infirmum deferat sacratissimum Corpus Christi, statim accedens ad ecclesiam pulset maiorem campanam suam ita quod per parochiam audiatur, et tunc parochiani super hoc a presbyteris eruditi ad ecclesiam veniant festinanter, pro societate usque ad domum infirmi dicto venerabili Sacramento et sacerdoti humiliter facienda. Et interim presbyter abluat manus suas, et procedens cum lumine, aqua benedicta et campanula ad infirmum, populus eundem, bini ac bini, humiliter subsequatur; et dum presbyter infirmo sacram Eucharystiam ministrabit, populus ipsum et Sacramentum ad hostium expectabit, et cum eodem presbytero revertente usque ad ecclesiam pariter revertentur". See also Schlessisches urkundenbuch, Bd. III, no. 346, p. 213. 
ed the habit of abducting women, often with the knowledge and consent of their families. The priest solemnizing the marriage was obliged to ask the woman whether she had been abducted and whether there was any pressure asserted on her. In order to avoid irregularities in the pastoral care of the faithful, the archdeacon of Liege obliged archdeacons to visit the parishes within their jurisdiction ${ }^{45}$.

As mentioned at the outset, the matters of the Polish Church were governed by papal legates delegated to Central European countries, outside Poland also. An excellent example of this was the Synod of Buda, proceeded in 1279 by Papal Legate Philip of Fermo ${ }^{46}$. A number of important legal regulations to be applied in Poland and Hungary were promulgated during the synod. However, the scope of Philip's legate jurisdiction was considerably broader, and included, apart from the territories mentioned above, also Croatia, Serbia, Dalmatia and other Balkan territories. To improve the quality of the religious teaching of the faithful, Philip of Fermo instructed that priests explain to parishioners the mystery of the Holy Trinity, the seven sacraments, the importance of good deeds and a number of other matters of preaching nature ${ }^{47}$. On the other hand, in monasteries, monks were to be appointed to teach grammar, theology and logic in schools ${ }^{48}$. The legate also understood the higher religious awareness of the faithful, who were worried about the eschatological fate of children who died before the sacrament of baptism. Baptisms could be performed even at those parishes that were interdicted. Philip of Fermo also instructed priests to teach all people, including children, how to perform baptism in the formula "I baptize you in the name of the Father and Son and Holy Spirit" in order to be able to perform baptism themselves in case of emergency ${ }^{49}$.

The legates, using their powers, enacted certain laws for Polish ecclesiastical institutions (such as legate Humbald for the monastery in Trzemeszno ${ }^{50}$ ), and also settled disputes between various church institutions. One of such activities is the decision of Legate Nicholas of Ostia, who stayed in Poznań in May 1302, regarding a dispute between Dominican nuns and the cathedral chapter ${ }^{51}$. In 1235, Legate Wilhelm, the bishop of Modena, settled the issue of pastoral control over the Cistercian nuns monastery in Trzebnica in favour of the Cistercian abbey in Lubiąz ${ }^{52}$. The legates also represented the papacy in diplomatic activities: it is worth mentioning the mission of Legate Guido in

${ }^{45}$ Canon Contra archidiaconos non visitantes, $K D W$, vol. 1, no. 274.

${ }^{46} K D W$, vol. 1 , no. 487.

47 SKRZYNIARZ, R., Nauczanie średniowiecznego Kościoła polskiego w świetle kazań świętokrzyskich i kazań gnieźnieńskich, [in:] Średniowieczny Kościót polski. Z dziejów duszpasterstwa i organizacji kościelnej, ed. M. T. ZAHAJKIEWICZ, S. TYLUS SAC, Lublin 1999, p. 93.

${ }^{48} \mathrm{KDW}$, vol. 1 , no. 487, p. 443. De studio monachorum.

49 See: KŁOCZOWSKI, J., Dzieje chrześcijaństwa polskiego, p. 69.

${ }^{50}$ See more on the topic in: WENTA, J., "Na marginesie dokumentu legata Humbalda z 2 marca 1146 roku dla Trzemeszna", Roczniki Historyczne, 1987, 53, p. 101-114.

${ }^{51} K D W$, vol. 2, no. 852 .

${ }^{52}$ Schlesisches Urkundenbuch, Bd. II: 1231-1250, ed. W. IRGANG, Wien-Köln-Graz 1977, no. 103. 
1148 for the duchess Agnieszka, wife of Władysław the Exile ${ }^{53}$. Guido was the legate for Poland and the neighbouring, newly converted countries. It also happened that the legates, on the behalf of the papacy, imposed canonical punishments on Poland, as it was in the case of Legate Opizzon, who in March 1254 put an anathema on Duke Przemysł I and covered his lands with an interdict as a punishment for the invasion of the bishop's duchy of Oleśnica ${ }^{54}$.

In 1309, the Gentilis' legatine synod was held in Poznań, which issued statutes for the Polish Church ${ }^{55}$. Their content does not bring new facts for our considerations, it covers clergy disciplinary issues, the condemnation of concubinage, combating the schismatics, etc. Gentilis pointed to the issue of properly educating the clergy, who in turn should take proper care of religious education of the faithful.

An interesting issue is how the teaching of the popes, council documents and collections of ecclesiastical law were distributed in Poland and what role was played by Apostolic legates in this process. It seems that their influence was considerable. An excellent example of this is the history of the manuscript Ms 84 from the Wawel cathedral library, containing papal decrees and writings of selected Church Fathers. The book had been written around 1099-1110, and was rewritten in Krakow during the legatine synod ${ }^{56}$. What is very important, the code contains provisions of the Rule of Aachen governing the functioning of canonical communities, including the matters of education of its members. The origins of the manuscript may be linked with the establishment of a cathedral school in Krakow ${ }^{57}$. Even earlier, in the times of Bolesław the Brave, Papal Legate Guido brought to Poland a collection of canon law, currently known in two Polish copies: of Krakow and Gniezno $^{58}$. The legates also brought copies of the Decrees of Pope Gregory IX ${ }^{59}$ to Poland. This text is of paramount importance for the development of ecclesiastical education, and refers in this respect to parish churches, where schools should operate, if possible ${ }^{60}$.

${ }_{53}$ The request for an intervention was submitted to Pope Eugene III by the King of Germany. See $K D S$, vol. 1, no. 19-21. King Henry himself took various diplomatic efforts aimed at restoring Agnieszka's position in Poland. Ibidem, no. 23; no. 24; no. 28-30.

${ }^{54}$ See an account in: Kronika wielkopolska, chapter 103.

${ }^{55} \mathrm{KDW}$, vol. 2, no. 928.

${ }^{56}$ More on the topic in: SZYMAŃSKI, J., "Krakowski rękopis reguły akwizgrańskiej z roku około 1103”, Studia Źródłoznawcze, 1966, 11, p. 39-52.

${ }^{57}$ Although the first scholastic in Krakow is reported in historical sources only in 1166, there is no doubt that the Krakow cathedral school had existed since the turn of the 10th and 11th centuries. On the first Krakow's scholastic, see the document published in Kodeks Dyplomatyczny Katedry Krakowskiej, vol. 1, no. 1.

58 SKWIERCZYŃSKI, K., Recepcja idei gregoriańskich $w$ Polsce, p. 265.

59 Ibidem, p. 269.

60 “ - - presbyter habens populum debet habere clericum, qui secum cantet et aliis hic expressis eum iuvet, ut quisque presbyter, qui plebem regit, clericum habeat, qui secum cantet, et epistolam et lectionem legat, et qui possit scholar tenere, et monere suos parochia nos, ut filios ad fidem discendam mittant ad ecclesiam, quos ipse cum omni castitate erudiat" as cited in: NIESZWIEC, R., Szkoła kolegiacka w Opolu do sekularyzacji, [in:] Kultura edukacyjna na Górnym Śląsku, ed. A. BARCIAK, Katowice 2002, p. 53. 
Legates convoked legatine synods, where they promulgated canons. At legatine synods, members of the higher clergy foregathered, led by the Archbishop of Gniezno, and also heads of monasteries and representatives of the lower clergy. The legates approved the election of bishops, visited the dioceses, consecrated clergymen and temples, and in the exercise of extraordinary judicial powers they heard appeals against rulings of episcopal courts. A specific feature of the legatine synods was the passive participation of Polish participants. Papal representatives usually presided over the local synods, even if they were of lower rank than the dignitaries gathered there ${ }^{61}$. It is noteworthy that, unlike the Polish provincial or diocesan synods, the legislation of legatine synods quickly became forgotten, as legate Guido complained about in $1267^{62}$. It is regrettable that the Legates did not succeed in enforcing the instructions of the Fourth Lateran Council that theologians be appointed at episcopal Cathedrals, to explicate the Holy Bible to priests and seminarians and to prepare them for pastoral work. The quite low level of teaching in Polish cathedral schools made it necessary to send clerics to study abroad, which, however, contributed to the improvement in the quality of spiritual education in Poland. The situation improved considerably after the the University of Krakow had been established. In line with the Council's requirements, the classes of theology and canonical law were organized only in Gniezno (and not until 1426) and in Poznań (in 1424), in the latter case limiting to theology classes. I needs to be stressed that the curriculum was similar to the university one, and these classes were to educate the diocesan clergy, including the parish clergy ${ }^{63}$.

The legatine synods held by Jacques of Liége (1248, 1264), Guido (1267), Philip of Fermo (1279) and Gentilis of Montefiore (1309) were of particular importance in terms of introducing the provisions of canon law to Poland in their educational aspect.

The apostolic legates were definitely a factor that accelerated the process of reception of particular church legislation in Poland, which is particularly true for the great reformist councils - the third and the fourth Lateran councils. In both cases, the activity of legations significantly increased, which was related to the performance of synods by representatives of the Holy See, during which they familiarized the Polish hierarchs with legal provisions enacted at general councils, and presented compilations of the canon law. This reception was not always straightforward, as many changes, especially in the field of discipline and celibacy of clergymen, faced understandable resistance of church circles ${ }^{64}$.

${ }^{61}$ SKWIERCZYŃSKI, K., Recepcja idei gregoriańskich w Polsce, p. 271-273.

62 "Volumus autem sub poena excommunicationis praecipentes, ut dominus arciepiscopus Gneznensis et eius suffraganei has constitutiones nostras sigillo nostro habeant singillas", Antiquissimae constitutions synodales provinciae Gneznensis, maxima ex parte nunc primum e condicibus manu scripti typis mandatae, ed. R. HUBE, Petropoli 1856, c. 11.

${ }^{63}$ OŻÓG, K., Wplyw środowiska uniwersyteckiego na ksztaltowanie i rozwój kultury religijnej w Polsce średniowiecznej, [in:] Animarum cultura. Studia nad kultura religijna na ziemiach polskich w średniowieczu, vol. 1: Struktury kościelno-publiczne, ed. H. MANIKOWSKA, W. BROJER, Warsaw 2008, p. 430.

${ }^{64}$ See: VETULANI, A., Z badań nad kultura prawnicza w Polsce piastowskiej, Wrocław 1976, p. 33 et seq. 
On the other hand, while assessing the importance of the legislation of legatine synods for the development of schools and education, two aspects, external and internal, should be discussed. The first case refers to the adoption in Poland of legal and organisational arrangements developed in Western Europe with regard to the functioning of schools and religious education of the faithful. One should consider the significant disproportions in the size of parish districts, the number of churches which was much smaller than in the West, the number and level of clerical education, or the vastness of Polish dioceses, making it difficult for the bishops to exercise due pastoral care. In any case, the legate's legislation attempted to reduce these disparities. In this respect, the desires of the legates coincided with internal Polish educational needs, which in turn resulted from economic and social transformations in Poland, which raised generation of educational aspirations, especially among burghers who, despite reluctance of church circles to establish new schools, demanded that new institutions be founded. Moreover, the fact that the Polish society was better educated, including religiously, required a new approach to pastoral care in the late Middle Ages, taking into account the growing requirements of believers. Finally, it is worth noting that the legacy of legatine synods was reflected in the legislation of Polish provincial and diocesan synods, which influenced in a much more specific way the image of religious education and school system in medieval Poland. The effect of the work of Papal legates included the revival of synodal life, visits to churches and monasteries, and the introduction of a unified ecclesiastical discipline.

\section{Bibliography}

\section{Sources}

Antiquissimae constitutiones sinodales provinciae Gnesnensis. Maxima ex parte nunc primum e condicibus manu scriptis typis mandata, ed. R. HUBE, Petropoli 1856.

Codex Diplomaticus Poloniae, vol. 1, Warszawa 1847.

Das Register Gregors VII, ed. E. CASPAR, [in:] Monumenta Germaniae Historica. Epistola selectae, Bd. 2, Berlin 1920-1923.

DŁUGOSZ, J., Annales seu Cronicae incliti Regni Poloniae, lib. V-VI, ed. M. PLEZIA, Warszawa 1973.

Dokumenty soborów powszechnych, vol. 2 (869-1312), ed. A. BARON, H. PIETRAS SJ, Kraków 2002.

GALL ANONIM, Kronika czyli dzieje książą i władców polskich, ed. K. MALECZYŃSKI, [in:] Monumenta Poloniae Historica. Series nova, vol. 2, Kraków 1952.

Kodeks dyplomatyczny katedry krakowskiej św. Wacława, ed. F. PIEKOSIŃSKI, vol. 1, Kraków 1874.

Kodeks dyplomatyczny Ślaska, vol. 1, Wrocław 1956.

Kodeks dyplomatyczny Wielkopolski, vol. 1-2, Poznań 1877-1878.

Kronika Wielkopolska, ed. B. KÜRBIS, [in:] Monumenta Poloniae Historica. Series nova, vol. 7, Warszawa 1970.

Kronikarze czescy. Kanonik Wyszehradzki, Mnich Sazawski, translated and compiled by M. WOJCIECHOWSKA, Warszawa 1978.

Rocznik wielkopolski, [in:] Monumenta Poloniae Historica, vol. 3, Lwów 1878. 
Schlesisches Urkundenbuch, Bd. 2-4, ed. W. IRGANG, Wien-Köln 1978-1988.

SUBERA, I., Synody prowincjonalne arcybiskupów gnieźnieńskich. Wybór tekstów ze zbioru Jana Wężyka z r. 1761, Warszawa 1981.

\section{Studies}

ABRAHAM, W., Studia krytyczne do dziejów średniowiecznych synodów prowincjonalnych Kościoła polskiego, Kraków 1917.

BANASZAK, M., „Biskupstwo poznańskie (problemy badawcze średniowiecznych dziejów), Nasza Przeszłość, 1988, 69.

BUCZEK., K., „Zagadnienie wiarygodności regestu Dagome iudex”, Studia Źródłoznawcze 1965, 10.

DERWICH, M., Mogilno i Płock. Z dziejów budowy organizacji Kościoła polskiego, [in:] Civitas et Villa. Miasto i wieś w średniowiecznej Europie Środkowej, Wrocław-Praha 2002.

DOBOSZ, J., Monarchia i możni wobec Kościoła w Polsce do poczatku XIII wieku, Poznań 2002.

GĘBAROWICZ, M., „Walo biskup Beauvais z Paryża i jego legacja w Polsce”, Sprawozdania Towarzystwa Naukowego we Lwowie, 1923, 3, vol. 1.

GÓRALSKI, W., „Statuty synodalne legata Jakuba z Leodium“, Prawo Kanoniczne, 1984, 27, vol. 3-4.

GROMNICKI, T., Synody prowincjonalne oraz czynności niektórych funkcjonariuszy apostolskich $w$ Polsce do r. 1357, Kraków 1885.

GRUDZIŃSKI, T., Polityka papieża Grzegorza VII wobec państw Europy Środkowej i Wschodniej (1073-1080), Torun 1959.

KŁOCZOWSKI, J., Dzieje chrześcijaństwa polskiego, Warszawa 2000.

KUMOR, B., Historia Kościoła w Polsce, vol. 1: do roku 1764, part 1: do roku 1506, ed. B. KUMOR, Z. OBERTYŃSKI, Poznań-Warszawa 1974.

KUMOR, B., Historia Kościoła, part 3: Złoty okres średniowiecza chrześcijańskiego, Lublin 2005.

KUMOR, B., Historia Kościoła, vol. 2: Wczesne średniowiecze chrześcijańskie, Lublin 1973.

LABUDA, G., „Początki diecezjalnej organizacji kościelnej na Pomorzu i na Kujawach w XI i XII wieku", Zapiski Historyczne 1968, 33, vol. 3.

LABUDA, G., Jakimi drogami przyszło do Polski chrześcijaństwo?, [in:] Idem, Szkice historyczne X-XI wieku. Z dziejów organizacji Kościoła w Polsce we wczesnym średniowieczu, Poznań 2004.

MALECZEK, W., Laterankonzil IV, [in:] Lexicon des Mittelalters, Bd. 5, München-Zürich 1991.

NIESZWIEC, R., Szkoła kolegiacka w Opolu do sekularyzacji, [in:] Kultura edukacyjna na Górnym Śląsu, ed. A. BARCIAK, Katowice 2002.

OŻÓG, K., Wpływ środowiska uniwersyteckiego na ksztaltowanie i rozwój kultury religijnej w Polsce średniowiecznej, [in:] Animarum cultura. Studia nad kultura religijna na ziemiach polskich w średniowieczu, vol. 1: Struktury kościelno-publiczne, ed. H. MANIKOWSKA, W. BROJER, Warszawa 2008.

PARAVICINI BAGLIANI, A., Kościót rzymski w latach 1054-1124: reforma i umocnienie papiestwa, [in:] Historia chrześcijaństwa. Religia, kultura, polityka, ed. J.M. MAYER et al., vol. 5: Ekspansja Kościoła rzymskiego 1054-1274, ed. A. VAUCHEZ, Warszawa 2001.

PARISSE, M., KŁOCZOWSKI, J., Władcy chrześcijańscy a Kościót. Spór o inwestyturę i jego skutki, [in:] Historia chrześcijaństwa. Religia, kultura, polityka, ed. J.M. MAYER et al., vol. 5: Ekspansja Kościoła rzymskiego 1054-1274, ed. A. VAUCHEZ, Warszawa 2001.

RATAJCZAK, K., „Ustawodawstwo szkolne soborów od XII do pierwszej połowy XIV w. i początki jego recepcji w średniowiecznej Polsce - zarys problemu", Biuletyn Historii Wychowania, $2007,23$. 
RATAJCZAK, K., Ustawodawstwo szkolne wczesnośredniowiecznych soborów powszechnych $i$ wybranych synodów. Zarys problemu, [in:] Ars Educandi. Źródła, vol. 1: Studia z dziejów wychowania i ksztatcenia od średniowiecza do XIX wieku, ed. J. GWIOŹDZIK, P.P. BARCZYK, Mysłowice 2009.

SILNICKI, T., Kardynat legat Gwido, jego synod wrocławski w r. 1267 i statuty tego synodu, Lwów 1930.

SKIERSKA, I., Obowiązek mszalny w średniowiecznej Polsce, Warszawa 2003.

SKRZYNIARZ, R., Nauczanieśredniowiecznego Kościoła polskiego w świetle kazań świętokrzyskich i kazań gnieźnieńskich, [in:] Średniowieczny Kościót polski. Z dziejów duszpasterstwa i organizacji kościelnej, ed. M.T. ZAHAJKIEWICZ, S. TYLUS SAC, Lublin 1999.

SKWIERCZYŃSKI, K., Recepcja idei gregoriańskich w Polsce do początku XIII wieku, Wrocław 2005.

SZYMAŃSKI, J., „Krakowski rękopis reguły akwizgrańskiej z roku około 1103”, Studia Źródłoznawcze, 1966, 11.

VETULANI, A., Z badań nad kultura prawnicza w Polsce piastowskiej, Wrocław 1976.

WENTA, J., „Na marginesie dokumentu legata Humbalda z 2 marca 1146 roku dla Trzemeszna”, Roczniki Historyczne, 1987, 53.

ZIELIŃSKI, J., „Legacja Piotra z Kapui do Czech i Polski w r. 1197”, Collactanea Theologica, 1957, 28, vol. 3-4.

Originally published in "Biuletyn Historii Wychowania", 2010, vol. 26, pp. 7-18 
